This is the final peer-reviewed accepted manuscript of:

Guglielmi, D., Bruni, I., Simbula, S. et al. What drives teacher engagement: a study of different age cohorts. Eur J Psychol Educ 31, 323-340 (2016)

The final published version is available online at: 10.1007/s10212-015-0263-8

Rights / License:

The terms and conditions for the reuse of this version of the manuscript are specified in the publishing policy. For all terms of use and more information see the publisher's website.

This item was downloaded from IRIS Università di Bologna (https://cris.unibo.it/)

When citing, please refer to the published version. 


\title{
What drives teacher engagement: a study of different age cohorts
}

\section{Dina Guglielmi $^{1}$ Ilaria Bruni ${ }^{2}$ Silvia Simbula ${ }^{3}$ Franco Fraccaroli $^{4}$ Marco Depolo $^{2}$}

\begin{abstract}
Despite the growing body of research on work engagement, little is known about what drives work engagement among different age cohorts. This study aims to investigate whether engagement varies across age cohorts and examine the job resources that foster teacher engagement. A questionnaire was distributed to 537 teachers who were employed in elementary, lower and upper secondary school. Findings show that work engagement did indeed vary across the diverse age group and is influenced by different resources. In line with previous studies, data revealed that the engagement of younger teachers is driven by the opportunity for development and interaction with colleagues, while older employees appreci-ate the opportunity to see their competencies acknowledged. What is most noteworthy is the opportunity to design practices and to provide every age group with the appropriate set of motivators.
\end{abstract}

Dina Guglielmi

dina.guglielmi@unibo.it; http://www.edu.unibo.it/it

Ilaria Bruni

ilaria.bruni@unibo.it

Silvia Simbula

silvia.simbula@unimib.it

Franco Fraccaroli

franco.fraccaroli@unitn.it

Marco Depolo

marco.depolo@unibo.it; http://www.psicologia.unibo.it/it

Department of Educational Sciences, University of Bologna, Via Filippo Re 6, 40127 Bologna,

2 Italy Department of Psychology, University of Bologna, Viale Berti Pichat 5, 40127 Bologna,

3 Italy Department of Psychology, University of Milano-Bicocca, Piazza dell'Ateneo Nuovo 1, 20126 Milan, Italy

4 Department of Psychology and Cognitive Science, University of Trento, Corso Bettini 84, Rovereto, 38068 Trento, Italy 
Keywords Teacher $\cdot$ Work engagement $\cdot$ Age $\cdot$ Job resources

\section{Introduction}

Teaching is a highly demanding profession, often characterised by an excessive workload, the failure of pupils to work or behave properly, poor relationships with colleagues, lack of suitable resources, constant changes within the profession and difficult interactions with the parents of students (Santavirta et al. 2007). Our aim is to understand what may help teachers in overcoming such issues and boost higher levels of energy, work involvement and concentra-tion, which in turn have been shown to affect job satisfaction (Høigaard et al. 2012) and employee performance (Salanova et al. 2005). In the present study, we have used the work engagement model (Bakker and Demerouti 2008) to investigate what key resources are involved in the building of work engagement. Engaged employees are enthusiastic, completely involved in their job and able to solve the problems that may occur (Bakker et al. 2008). If this is true for any worker, it is even more salient in the teaching profession, as research has shown that engaged teachers are able to improve students' performance and their preparation for the future (Bakker 2005; Kahn 1990). Moreover, the more engaged teachers are, the less willing they are to leave their job (Bakker et al. 2003).

Teachers are also likely to have different needs and experiences at different points in their careers (Lavigne 2014). As teachers gain more experience, ulterior and different influences affect teachers the longer they have worked in their profession (Canrinus et al. 2012). Teachers' career stages have been the object of several investigations. The majority of studies have focused on a specific stage, such as early career (e.g. Fernet et al. 2014; Le Cornu 2013; Mansfield et al. 2014), while fewer have taken into account the midcareer stage (e.g. Farrell 2014), and only small proportion have considered the entire career progression.

According to Super (1957), working life consists of three broad phases: a trial stage, a maintenance phase, and a late career stage. The existence of different work stages in the teacher's career has been recognised also by Day et al. (2006); in a sample of 1143 English teachers, they found that the first years $(<8$ years $)$ of the teaching profession are characterised by the development of commitment and a sense of efficacy. The central years (824 years) of the career constitute a challenge balancing work and life domains, and almost 25 $\%$ of teachers begin to show detachment and loss of motivation. The final years ( $>25$ years) see a significant difference between primary and secondary school teachers. While the first category retains a strong motivation, the other is found to be losing it. Another study supporting the use of three phases is Borman and Dowling's (2008): Their meta-analysis shows that drop-out among teachers is high at the beginning of the career, very low during midcareer, and high again as teachers approach retirement. As this study is interested in studying teacher work engagement across different life and career stages, we decided to make a comparison of three successive age groups. The career stage perspective has also been adopted by Van der Heijden's (2006), although there was no reference to the teaching profession, she found that for profit sector employees, career activities varied between starters (20-34 years), middle-aged workers (35-49) and seniors (over-fifties), whereas less differences between age groups were found for the non-profit sector employees.

Based on the evidence presented, this study is interested in studying how job resources and work engagement vary across different age groups and examine the factors that play a role in fostering teacher engagement. 


\section{Work engagement and age}

As anticipated, the present research has been based on Bakker and Demerouti's (2008) work engagement model. Work engagement is a positive, work-related state of mind characterised by vigour (i.e. high levels of energy and resilience at work and willingness to invest on the job), dedication (i.e. being involved in one's work, enthusiasm, inspiration) and absorption (i.e. being happily engrossed in one's work so that one has difficulties to detach from the tasks being performed) (Schaufeli et al. 2002). Engaged employees are supported by high levels of energy and feel enthusiastic about their work. Furthermore, they are often so immersed in their work that do not perceive time passing (Bakker and Demerouti 2008). Trends associated with the aging of the workforce have made it important to consider whether employee age, tenure with their company, life-stage and career-stage are related in any way to their engagement (Pitt-Catsouphes and Matz-Costa 2008). To this end, Schaufeli et al. (2006) used a large sample of employees and pointed out that age and engagement are both positively related, although this relationship was too weak to be considered meaningful. In a similar vein, Robinson et al. (2004) found that workers over the age of 60 were the most engaged among all ages of employees. Again, these results have been recently replicated by two different studies: On the whole, these empirical findings suggest that older workers are more engaged than their younger colleagues (PittCatsouphes and Matz-Costa 2008; James et al. 2011). All considered, this data underlines that significant variations between different age groups exist, although this aspect has been rarely taken into account. In particular, to the best of our knowledge, no study seems to have investigated whether age is related to engagement experience in the teaching profession. Therefore, we have reported and based this work on the findings of the few studies that have tested the impact of age on employee engagement.

\section{What drives engagement}

In line with traditional motivational approaches such as the job characteristics model (Hackman and Oldham 1980) and the self-determination theory (Ryan and Deci 2000), work engagement is primarily fostered by those working conditions that help build dedication to and identification with work, i.e. job resources (Demerouti et al. 2001). Job resources refer to those physical, social or organisational aspects of work that may reduce the impact of job demands and foster personal development and learning (Bakker and Demerouti 2007; Schaufeli and Bakker 2004). Numerous studies have consistently shown that work engagement is driven by job resources (just to cite the most recent studies: Airila et al. 2014; Lee and Ok 2015; Lorente et al. 2014). This process, in which resources influence engagement, is called 'motivational process' in the Job demands-resources model (Demerouti et al. 2001) and is described as enhancing intrinsic motivation. However, the same authors stated that job resources can also play an extrinsic motivational role by stimulating the willingness to dedicate one's effort and abilities to the work tasks, thus being instrumental to achieve work goals (Bakker and Demerouti 2008). Research in the educational sector has found evidence in the relationships between work engagement and several job resources: interactions with pupils (Runhaar et al. 2013), social support and learning opportunities (Simbula et al. 2011), appreciation and organisational climate (Bakker et al. 2007), job control, information, social climate and innovativeness (Hakanen et al. 2006). These studies show that there are a number of job resources that may play a significant role in influencing teachers' work engagement. In our 
study, we decided to take into account those that are more relevant to the Italian school context. On the one hand, several changes have occurred in the recent years, such as changes in the local management of schools and appraisal of teacher performance. On the other hand, the fact that monetary rewarding is not available to the management raises the issue of recognising personal effort and finding alternative resources to sustain teacher engage-ment. For instance, a resource that has consistently been shown to foster employee engagement is learning opportunities (e.g. Hu et al. 2011; PittCatsouphes and Matz-Costa 2008). At the same time, role clarity has been shown as a major issue in school, as education systems are facing new challenges and the teaching profession is characterised by ambiguous job definitions and a lack of formal procedures (Somech and Drach-Zahavy 2000). Teachers are expected to teach, care for the psychological equilibrium of their pupils and help their social integration (Esteve 2000). Given the number of tasks required of teachers, a clear definition of role expectations may foster teacher engagement. Another asset to good organisational design, and insofar as good levels of engagement, is teacher personal responsibility. Responsibility has important motivational implications as it fosters effort investment, persistence and commitment (Lauermann 2014); in fact, previous research shows that it relates positively to work engagement (see Matteucci and Guglielmi 2014). Employees are also sensitive to remunerative justice. When workers have high perceptions of justice in their organisation, they are more likely to feel obliged to be fair in return on how they perform their roles by giving more of themselves through greater levels of engagement (Saks 2006; Ghosh et al. 2014). The motivating connection between the worker and the workplace, which goes beyond the utilitarian exchange of time for money or advancement, is through work values that are the ideals and motivations that originally attracted people to their jobs (Maslach and Leiter 2008). This motivating process results in higher engagement, especially when intrinsic work values are involved (Sortheix et al. 2013). Interpersonal relationships are other job resources, a potential source of influence on engagement. Its influence is twofold: On the one side, interaction and support from colleagues have consistently shown to boost employee engagement, and at the same time, external validation represents the opportunity for teachers to gain professional recognition and being acknowledged as role models. As Hildebrandt and Eom (2011) showed, validation from others along with career advance-ment and enhanced leadership serve as strong incentives for teachers.

Despite the growing body of research on work engagement, little is known about what job resources influence it among different age cohorts. To the best of our knowledge, only few studies focused on this subject. For instance, PittCatsouphes and Matz-Costa (2008) report a large number of drivers that differentiate younger and older worker cohorts. Satisfaction with training and development and a perception of security strongly predict engagement of younger workers, while older workers are influenced by supervisor status and higher work overload. On the contrary, the work by James et al. (2011) found no differences in engagement determinants between the diverse age groups, with the exception of career development and promotion, which appears to be less important to older employees. Based on the aforementioned considerations, our research questions are the following:

- Does teacher engagement differ on the basis of age?

- Do job resources vary across age cohorts?

- What job resources foster teacher engagement and do the effects vary by age? 


\section{Materials and methods}

\section{Data collection}

Data was collected within a project commissioned by IPRASE (Trento). The project aimed to provide a description of the potential of those working within the schools in terms of involvement and attitude towards their work. The research was presented to school principals who in turn reported to the board of governors. Members of the research team distributed the research tool (i.e. a questionnaire). Participation was requested but not mandatory. Every school nominated a representative to solicit colleagues' support and monitor the collection of questionnaires. Once the questionnaire was completed at home, teachers were asked to insert it in a box so that the participants remained anonymous. At the end of the project, each school illustrated the main findings emerged from the survey.

\section{Participants}

Five hundred thirty-seven Italian teachers fulfilled the questionnaire (response rate reached $70.4 \%$ ). Women were $75 \%$ of the sample. The average age was 42.85 (S.D. =9.91). Age in particular was well distributed: $24.2 \%$ of the respondents were less than 34 years old (starters), $45.6 \%$ were 35-49 (middle-aged) and 30.2\% were over 50 (seniors). Participants taught in a number of different schools: $47.1 \%$ of them taught in primary school, $31 \%$ taught in lower secondary school and the remaining $21.9 \%$ taught in upper secondary school. A total of $22.3 \%$ have worked for 5 years or less, $14.7 \%$ for $6-10$ years, $26.1 \%$ for $11-20$ years, $21.5 \%$ for $21-$ 30 years and $15.4 \%$ for more than 30 years.

\section{Age categories}

Given that this study is particularly interested in the differences between different age cohorts, the authors decided to make a comparison of three successive age groups of the working population namely starters (20-34 years), middle-aged (35-49 years) and seniors (50+). As in Van der Heijden's (2006) study of career activities, this division was proposed for several reasons: It covers the whole career span, it provides age groups with a similar range and it frames a category of workers experiencing mid-life changes.

Even though seniority is not always equivalent to age, what we posit is that age homogeneous groups are preferable, as life stages bring the individuals to experience similar patterns and challenges. Moreover, as Kanfer and Ackerman (2004) stated, age and agerelated changes play a key role in successful work outcomes.

\section{Control variables}

We identified control variables that might affect our findings: gender and school type. We anticipated that these variables might affect teacher engagement. For instance, prior evidence has indicated women to be more engaged than men (Mauno et al. 2005; Rothbard 2001). Regarding the school membership, evidence shows that primary school teachers experience more dedication and absorption in their work than do secondary teachers (Timms et al. 2007). 
We created dummy variables and used them in regression analyses. Gender was dummycoded $(0=$ male; $1=$ female $)$. Furthermore, we controlled for the type of school in which teachers were employed. We created two dummy variables in which the category 'upper secondary school' was the point of reference when constructing the dummies.

\section{Measures}

Engagement The short version of the Utrecht Work Engagement Scale (Schaufeli et al. 2006; Italian validation: Balducci et al. 2010) was used, consisting of a nine-item scale (three for each dimension): vigour (e.g. 'During my work, I feel bursting with energy'), dedication (e.g. 'My job inspires me') and absorption (e.g. 'I am immersed in my work'). We followed Schaufeli et al. (2006) recommendation and computed an overall engagement score of the UWES, which we used in the analyses. All items related to dimensions of engagement were scored on a seven-point scale ranging from '0' (never) to '6' (always).

Role clarity Role clarity is defined as the extent to which individuals clearly understand the duties, tasks, objectives and expectations of their work roles (Hinkin and Schriesheim 2008). This dimension was measured with a five-item scale (Italian validation: Almudever et al. 2000; Rizzo et al. 1970). An example of the items is 'Often I have to do things that have nothing to do with teaching (reversed)'. The scores ranged from ' 1 ' (strongly disagree) to ' 5 ' (strongly agree).

Learning opportunities Learning opportunities represent the extent to which the context at work provides stimuli for individual learning and allows the skills and competences of the workers to be used while carrying out the work (Panari et al. 2010). This construct was measured with a five-point Likert scale developed by Borgogni et al. (2005). The scale consists of four items such as 'This work is improving my skills', and the scores ranged from ' 1 ' (strongly disagree) to ' 5 ' (strongly agree).

Responsibility Responsibility refers to a sense of internal obligation and commitment to produce or prevent designated outcomes, or that these outcomes should have been produced or prevented (Lauermann and Karabenick 2011). It was measured with a fivepoint Likert scale developed by Guglielmi et al. (2011). It consists of four items such as 'I find myself taking on responsibilities that should not be mine' (reversed). The scores ranged from ' 1 ' (never) to ' 5 ' (always). Higher scores meant that individuals felt an adequate amount of responsibility.

Colleague support Colleague social support refers to actions and positive relationships, such as perceived availability of help, or actually received support from coworkers (Schwarzer and Knoll 2007). To explore the relationships with colleagues, we used five items measured on the five-point Likert scale (Agervold and Mikkelsen 2004; Italian validation: Guglielmi et al. 2011). One example of the items is 'There is collaboration between colleagues'. Workers could answer on a scale from ' 1 ' (never) to '5' (very often).

Remunerative justice This construct was measured with a single item created ad hoc for this research. The item is 'Do you believe that your salary is adequate for carrying out your job?' Answers were on a scale ranging from ' 1 ' (not at all suitable) to '5' (entirely appropriate). 
Social recognition Social recognition refers to trustworthiness and reliability, and being recognised in the workplace as an expert by significant individuals. It is characterised on the one side by the ability to impact and influence colleagues, on the other side by the ability to build and develop relationships (Van der Heijden 1998). We used a five-item scale developed by Van der Heijden (1998), which was already tested in the Italian context (Guglielmi and Sarchielli 2006). One example of the items is 'I am the point of reference for my colleagues'. The scores ranged from ' 1 ' (strongly disagree) to ' 5 ' (strongly agree).

Work values A ten-item scale was used to assess work values (MOW 1987; Depolo 1998). The MOW International Research Team study (1987) stated that work values can be intrinsic, when related to the degree of importance to immaterial aspects of the jobs that foster self-expression and extrinsic, which focus on material work aspects, such as retribution and opportunity for promotion. Therefore, six items represented the intrinsic dimension (autonomy, opportunity to learn new things, variety, relationships with supervisors, interest, relationships with colleagues), and the other four the extrinsic dimension (physical work environment, work security, salary, work schedule). Workers indicated the degree to which intrinsic and extrinsic values were important to them. The scores ranged from ' 1 ' (not important at all) to ' 5 ' (vital).

\section{Strategy of analysis}

In order to answer the research questions, we first performed descriptive statistics and Pearson's correlation analyses between all variables under study. As a rule of thumb (Hinkle et al. 2003), correlation coefficients whose magnitude are between 0.9 and 1.0 indicate variables which can be considered very highly correlated, magnitude between 0.7 and 0.9 indicate variables which can be considered highly correlated and magnitude between 0.5 and 0.7 indicate variables which can be considered moderately correlated. Correlation coefficients whose magnitude is be-tween 0.3 and 0.5 indicate a low correlation. Finally, correlation coefficients whose magnitude is less than 0.3 have little, if any (linear), correlation.

Moreover, a multivariate analysis of variance (MANOVA) was performed to evaluate statistically the differences between the three age groups in all scales presented above. We also included gender and school level as fixed factors, in order to check for potential interaction effects with age groups. Where necessary, we conducted follow-up univariate and post hoc Tukey tests to determine the pairwise differences among variables for our groups. As an estimate of effect size for group mean differences, we calculated the partial eta squared $\left(\eta^{2}\right)$. Partial eta squared measures the proportion of variability associated with an effect when the variability associated with all other effects identified in the analysis has been removed from consideration (Richardson 2011). Cohen (1969) has suggested values of 0.0099, 0.0588 and 0.1379 , respectively, to indicate small, medium or large effects for this measure of the proportion of variance explained.

Finally, multiple regression analysis was used to estimate the effects of the job resources (role clarity, responsibility, learning opportunities, colleague support, social recognition, remu-nerative justice, intrinsic and extrinsic work values) on work engagement. Separate regression analyses were performed for each of the three age categories. We also added Cohen's $f^{2}$ value as an estimate of multiple regression effect size. As rule of thumb, effect sizes of $0.02,0.15$ and 0.35 are considered small, medium and large, respectively (Cohen 1998). 


\section{Results}

Means, coefficient alphas and correlation coefficients of the study variables are provided in Table 1. Internal consistency of the scales was acceptable, with the exception of the learning opportunities scale and extrinsic work values, which are slightly under the usually accepted threshold value of 0.70 (Nunnally and Bernstein 1994). As correlation analysis shows, engage-ment is significantly related to every variable apart from gender and secondary school, even though all coefficients are small. Further analyses will explore these relationships in detail.

\section{MANOVA analysis}

Using a general linear multivariate analysis of variance (GLM MANOVA), we evaluated statistically the differences between the three age groups on all scales presented above. In order to control for gender and type of school, we also included these variables as fixed factors in the analysis. Where necessary, we conducted follow-up univariate and post hoc tests to determine the pairwise differences among variables for our groups. Results from the first GLM MANOVA revealed an overall significant multivariate effect of age group, with Wilks' $\lambda=0.83, F(18,960)=5.39, p=0.000$, partial $\eta^{2}=0.09$, as an overall significant multivariate effect of school, with Wilks' $\lambda=0.91, F(18,960)=2.67, p=0.001$, partial $\eta^{2}=0.05$. No significant multivariate effects were found for gender or for any interaction effect between variables.

Subsequent univariate analysis of variance (ANOVAs) indicated that the age groups differed significantly on all variables except for extrinsic work values (Table 2). Moreover, as we mentioned above, Cohen (1969) has suggested values of 0.0099, 0.0588 and 0.1379 , respectively, to indicate small, medium or large effects for partial eta squared. Thus, in our analysis, the proportion of variance between engaged groups can be considered from small to medium magnitude (see Table 2).

Post hoc Tukey tests were applied for pairwise comparisons. Results revealed that the younger teachers in particular were different from the other groups. To be specific, with respect to the perception of role clarity and responsibility, younger teachers showed a significantly higher mean than all the other groups, and they perceived more intrinsic work values than older teachers. Concerning the perception of remunerative justice, learning opportunities and colleague support, the younger teachers were found to have significantly higher ratings than those in the middle group (35-49 years old). Finally, starters were again found to be more engaged than their older $(50+)$ colleagues. However, in their perception of social recognition, the pattern was opposite: That is, older teachers perceived more social recognition than their younger colleagues.

Concerning school type, subsequent ANOVAs indicated that the groups differed signifi-cantly on role clarity $(F(2 ; 488)=3.63, p<0.05)$, responsibility $(F(2 ; 488)=7.59$, $p<0.01)$ and social recognition $(F(2 ; 488)=4.95, p<0.01)$. To be specific, primary school teachers showed lower levels of role clarity and responsibility in comparison with both lower and upper secondary school teachers, whereas they showed lower levels of social recognition than upper secondary school teachers.

\section{Multiple regression analysis}

Regression analysis was used to estimate the effects of job resources on work engagement. Separate regression analyses were performed for each of the three age categories (Table 3). The 


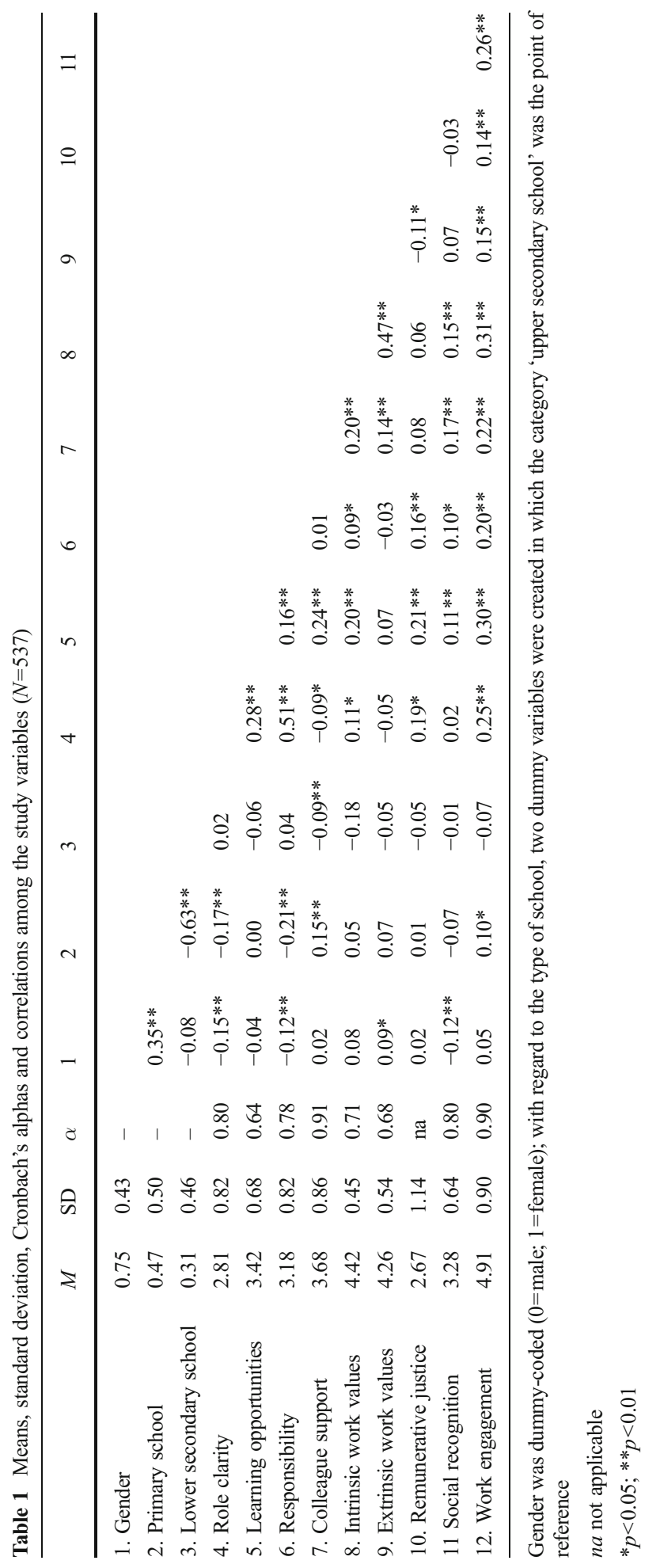


Table 2 Results of ANOVA between groups: age

\begin{tabular}{|c|c|c|c|c|c|}
\hline & $\begin{array}{l}\text { Starters }(\leq 34) \\
n=126 \\
M(S D)\end{array}$ & $\begin{array}{l}\text { Middle-aged (35-49) } \\
n=234 \\
M(S D)\end{array}$ & $\begin{array}{l}\text { Seniors }(\geq 50) \\
n=146 \\
M(S D)\end{array}$ & $F(2 ; 488)$ & Partial $\eta^{2}$ \\
\hline Work engagement & $5.12(0.10) \mathrm{a}$ & $4.89(0.08) a, b$ & $4.63(0.09) \mathrm{b}$ & $6.59 * *$ & 0.03 \\
\hline Role clarity & $3.29(0.09) \mathrm{a}$ & $2.76(0.07) \mathrm{b}$ & $2.73(0.08) b$ & $14.30 * * *$ & 0.06 \\
\hline Responsibility & $3.55(0.08) \mathrm{a}$ & $3.15(0.07) b$ & $3.13(0.08) b$ & $7.68 * *$ & 0.03 \\
\hline $\begin{array}{l}\text { Learning } \\
\text { opportunities }\end{array}$ & $3.61(0.08) \mathrm{a}$ & $3.37(0.06) b$ & $3.42(0.07) a, b$ & $3.28 *$ & 0.01 \\
\hline Colleague support & $3.89(0.10) \mathrm{a}$ & $3.46(0.08) b$ & $3.57(0.09) \mathrm{a}, \mathrm{b}$ & $6.40 * *$ & 0.03 \\
\hline Social recognition & $3.06(0.07) \mathrm{a}$ & $3.32(0.06) a, b$ & $3.45(0.07) \mathrm{b}$ & $8.29 * * *$ & 0.03 \\
\hline $\begin{array}{l}\text { Remunerative } \\
\text { justice }\end{array}$ & $3.13(0.13) \mathrm{a}$ & $2.55(0.10) b$ & $2.50(0.12) \mathrm{a}, \mathrm{b}$ & $8.08 * * *$ & 0.03 \\
\hline $\begin{array}{l}\text { Intrinsic work } \\
\text { values }\end{array}$ & $4.51(0.05) \mathrm{a}$ & $4.40(0.04) \mathrm{b}$ & $4.30(0.05) b$ & $4.32 *$ & 0.02 \\
\hline $\begin{array}{l}\text { Extrinsic work } \\
\text { values }\end{array}$ & $4.21(0.06) \mathrm{a}$ & $4.28(0.05) \mathrm{a}$ & $4.15(0.06) \mathrm{a}$ & 1.57 & 0.01 \\
\hline
\end{tabular}

Different lowercase letters denote significant differences between age groups based on Tukey post hoc paired comparisons (when the groups do not differ from one another, they all share the same superscript)

$* * * p<0.001 ; * * p<0.01 ; * p<0.05$

results show that the control variables have little effect on employee engagement. Only primary school membership has an impact limited to the senior group $(\beta=0.30, p<0.05)$.

Table 3 Multiple regression analysis

Work engagement

\begin{tabular}{|c|c|c|c|c|c|c|c|c|c|}
\hline & \multicolumn{3}{|c|}{$\begin{array}{l}\text { Starters }(<34) \\
R^{2}=0.321 ; F(11)=6.371 \\
\text { Cohen's } f^{2}=0.47\end{array}$} & \multicolumn{3}{|c|}{$\begin{array}{l}\text { Middle-aged }(35-49) \\
R^{2}=0.187 ; F(11)=5.876 \\
\text { Cohen's } f^{2}=0.23\end{array}$} & \multicolumn{3}{|c|}{$\begin{array}{l}\text { Seniors }(>50) \\
R^{2}=0.317 ; F(11)=7.126 ; \\
\text { Cohen's } f^{2}=0.46\end{array}$} \\
\hline & $B$ & $S E B$ & $\beta$ & $B$ & $S E B$ & $\beta$ & $B$ & $S E B$ & $\beta$ \\
\hline Gender & -0.22 & 0.15 & -0.13 & 0.17 & 0.13 & 0.08 & 0.20 & 0.18 & 0.09 \\
\hline Primary school & 0.30 & 0.16 & 0.19 & 0.07 & 0.14 & 0.04 & 0.63 & 0.24 & $0.30^{*}$ \\
\hline Lower secondary school & -0.13 & 0.17 & -0.07 & 0.02 & 0.14 & 0.01 & 0.41 & 0.23 & 0.19 \\
\hline Role clarity & -0.03 & 0.09 & -0.03 & 0.22 & 0.07 & $0.20 * *$ & 0.12 & 0.12 & 0.09 \\
\hline Learning opportunities & 0.25 & 0.10 & $0.20 *$ & 0.18 & 0.07 & $0.15^{*}$ & 0.18 & 0.13 & 0.11 \\
\hline Responsibility & 0.28 & 0.09 & $0.29 * *$ & -0.01 & 0.07 & -0.01 & 0.06 & 0.12 & 0.04 \\
\hline Colleague support & 0.30 & 0.08 & $0.29 * * *$ & -0.04 & 0.06 & -0.04 & 0.12 & 0.10 & 0.10 \\
\hline Intrinsic values & 0.48 & 0.18 & $0.24 *$ & 0.21 & 0.13 & 0.12 & 0.36 & 0.19 & 0.16 \\
\hline Extrinsic values & -0.08 & 0.12 & -0.06 & 0.15 & 0.11 & 0.10 & -0.08 & 0.15 & -0.05 \\
\hline Remunerative justice & 0.02 & 0.05 & 0.03 & 0.01 & 0.05 & 0.02 & 0.07 & 0.07 & 0.08 \\
\hline Social recognition & 0.15 & 0.09 & 0.13 & 0.38 & 0.08 & $0.29 * * *$ & 0.61 & 0.13 & $0.37 * * *$ \\
\hline
\end{tabular}

Gender was dummy-coded $(0=$ male; $1=$ female $)$; with regard to the type of school, two dummy variables were created in which the category 'upper secondary school' was the point of reference

$* p<0.05 ; * * p<0.01 ; * * * p<0.001$ 
None of the job resources had significant effects on engagement across all age categories. Indeed, results show several differences. Role clarity is positively related to engagement only for the middle-aged group $(\beta=0.20, p<0.01)$. Learning opportunities show significant positive effects on the starters $(\beta=0.20, p<0.05)$ and the middle-aged groups $(\beta=0.15, p<0.05)$. Responsibility $(\beta=0.29, p<0.01)$, colleague support $(\beta=0.29, p<0.001)$ and intrinsic values $(\beta=0.24, p<0.05)$ show significant effect on engagement only for the starters. Extrinsic work values and remunerative justice show no significant relationships with any of the groups considered. Social recognition has strong positive effects on the middle-aged $(\beta=0.29$, $p<0.001)$ and the senior groups $(\beta=0.37, p<0.001)$.

\section{Discussion}

The first objective was to verify whether teacher engagement differed on the basis of age. Younger teachers were found to be more engaged than their older $(50+)$ colleagues. Nevertheless, to our knowledge, there are no studies that deal with teachers' age and engagement, and this result confirms Day et al. (2006) findings that teacher involvement is high at the beginning of their career and Hildebrandt and Eom's (2011) that starters represent the most proactive and enthusiastic group but goes in the opposite direction compared with the previous studies that show older employees as more engaged than their younger counterpart (James et al. 2011; Pitt-Catsouphes and Matz-Costa 2008; Robinson et al. 2004). It seems noteworthy to underline that the first two studies were conducted with teachers, while the others collected data among other professionals. This difference confirms the value of investigating in the field of education, since specific features may have a different impact on workers, especially in Italy, where teachers become fully professionally qualified at an older age compared to their foreign colleagues. The specificities of the Italian context explain thus the differences with previous findings, such as Borman and Dowling's (2008) that beginners are more prone to attrition. In fact, balancing pros and cons of leaving the profession, the required long training and development of competencies may discourage starters from attrition, while Borman and Dowling (2008) postulate that beginners' decision to leave is due to the minor capital of specific knowledge accumulated that is knowledge specific to the occupation and non-transferable.

The second objective was to study the role of job resources across age cohorts. Pattern emerged from analyses suggests that younger teachers find more positive and motivating elements in their job than their older colleagues. Starters showed a significantly higher mean than all other groups with respect to their perception of role clarity, responsibility and intrinsic work values while perceiving more remunerative justice, learning opportunities and colleague support but less social recognition than the middle-age group. Unavoidable difficulties in first years of teaching jobs, such as the burden of multiple tasks or the mismatch between idealistic motivation and the reality of a classroom, are likely to be interpreted by younger teachers as temporary obstacles, compared with the success of having started their desired job. Clearly, social recognition (i.e. that is being recognised as expert by peers) does not play the same role at the beginning of teachers' career later on, while colleagues' support in particular plays a central role during these first years. In fact, by providing emotional and practical support to early career teachers, this feature has a positive effect on their self-confidence and their resilience (Le Cornu 2013).

The third objective was to investigate whether job resources predicted teacher engagement differently across age cohorts. Younger teachers' engagement is enhanced by the opportunity 
for personal development, responsibility, colleague support and intrinsic values. Job resources related to the levels of engagement among the middle-aged include role clarity and opportunity for development and social recognition, while seniors' engagement is boosted only by social recognition. In line with Pitt-Catsouphes and Matz-Costa's (2008) findings, younger teachers' engagement is driven by the opportunity for development and interaction with colleagues, while older employees appreciate the opportunity to see their competencies acknowledged. Middle-aged teachers are somehow at a turning point where they still benefit from the opportunity to develop but at the same time desire to be valued and recognised as a point of reference for their colleagues.

It is not surprising that starters seem to hold more positive attitudes towards their job, and their engagement appears driven by the desire for continuous development and intrinsic values. It has been shown to be an occupation closely linked to intrinsic work values, high expectations and personal involvement (Struyven et al. 2013). On the one hand, younger teachers may perceive a lesser need for approval when starting their career. Given the time spent in gaining the proper training and education, they are strongly driven by intrinsic motives. On the other hand, the continuous lack of incentives and development opportunities may start to have a stronger influence when approaching the following stages of career, when some older teachers, especially in secondary schools, are called upon to help in managerial tasks, such as filling the vice-principal role.

It seems noteworthy to underline the findings related to primary schools teachers compared to those working in secondary schools. On the one hand, they emerge as those perceiving less clarity, a less appropriate responsibility and less social recognition; on the other hand, for older teachers, working in a primary school seems to offer more opportunities for engagement. Among the main predictors of work engagement in senior teachers, we find working in primary school. These results partially cover what indicated by Day and colleagues' study (2006), which showed that teachers who work in primary schools are more likely to sustain their commitment and motivation over career than secondary teachers. The scholars found that primary teachers seemed to value positively certain situated factors within primary schools such as more opportunities for promotion and less complicated school structures.

\section{Practical implications}

Our results show that 'one size does not fit all'. When it comes to what employers could do to improve employee engagement, principals might want to focus on specific drivers of engagement for their teachers, according to particular age groups. Indeed, the age cohorts explored in our study have been shown to react to different resources. What is most noteworthy is the opportunity, for managerial and ethical reasons, to design appropriate practices to every age group.

Our data, along with the literature here presented, showed that younger teachers are mainly driven by responsibility, colleagues' support and learning opportunities. Among these job resources, we believe that it may be strategic to focus on the opportunity for professional development. Beginning teachers see it as an intrinsic motivator (increased professional self-efficacy) and an 'extrinsic' tool to build their career (the more skilled they are, the more likely that they will have a positive and successful career). Training is consequently one of the best human resource (HR) tools for this group, especially if these activities are under voluntary participation. Academic research has demonstrated that employees who are offered training and development program acquire job-related skills and competencies and demonstrate higher job performance (e.g. Aguinis and Kraiger 2009; Arthur et al. 2003). 
Training, however, may not be an equally useful strategy for older teachers. They have a narrower time perspective, which makes career development less attractive. At the same time, they do not perceive the need for further improving professional skills, because they feel sufficiently efficient due to their seniority. According to our data, seniors' engagement is driven by social recognition. This does not mean that other factors cannot play a role, but social recognition still stands as the best leverage for principals. Kanfer and Ackerman (2004) observed that aging individuals tend to lose fluid intellectual ability, which makes it difficult for them to compete with younger employees in terms of workload and rapidity. However, evidence showed a strong positive relationship between age and knowledge levels (e.g. Beier and Ackerman 2003). Thus, the opportunity for them to use the capital of accumulated knowledge and to perform more managerial tasks or support their peers should be regarded as the best tools to manage seniors. Even if seniority is not a substitute for competence, past experience can foster social and relational skills that are useful for coaching and mentoring. Senior members could see performing these roles as both worthwhile and gratifying while offering valuable services to the schools. In spite of the lack of extrinsic rewards and verbal praise, these teachers may overcome career frustrations and regain their enthusiasm.

Looking at our results, the same is not exactly true for middle-aged teachers. While social recognition could remain a booster for work engagement, role clarity emerged as a critical factor specifically for this group. As a consequence, one could suggest that school principals pay close attention to role design, since middle-aged teachers (no longer newcomers, and not yet fully masters of the work setting) seem especially sensitive to role clarity and its effects. At the same time, as previously stated, since the middle years of the career constitute a challenge in terms of what is required by both work and life domains, paying attention to the work/life interface, such as according flexible schedules or work permits, may reduce the discomfort perceived in the workplace.

\section{Limitations}

The study has some limitations each of which provides a basis for future studies. Firstly, the data is based on self-reported measures, and thus, there is the potential effect of social desirability. Secondly, the correlational design does not allow us to interpret the relationships found significant as causal relationships. Longitudinal studies are needed to examine stability in selfreported engagement. Moreover, the survey instrument includes a limited number of potential sources for teacher engagement. Future studies may assess additional factors and whether our findings are specific to the school context or may be generalised also to other organisations. 


\section{References}

- Agervold, M., \& Mikkelsen, E. G. (2004). Relationships between bullying, psychosocial work environment and individual stress reactions. Work and Stress.

doi:10.1080/02678370412331319794.

- Aguinis, H., \& Kraiger, K. (2009). Benefits of training and development for individuals and teams, organizations, and society. Annual Review of Psychology.

doi:10.1146/annurev.psych.60.110707.163505.

- Airila, A., Hakanen, J. J., Schaufeli, W. B., Luukkonen, R., Punakallio, A., \& Lusa, S. (2014). Are job and personal resources associated with work ability 10 years later? The mediating role of work engagement. Work and Stress.

doi:10.1080/02678373.2013.872208.

- Almudever B., Depolo M., Fraccaroli F., Hajjar V. (2000). Conflitto e ambiguità di ruolo: validità di costrutto di una scala nella versione francese e italiana. Bollettino di Psicologia Applicata. 230, 63--72.

- Arthur, W., Jr., Bennett, W. J., Edens, P., \& Bell, S. T. (2003). Effectiveness of training in organizations: a meta-analysis of design and evaluation features. Journal of Applied Psychology. doi:10.1037/0021-9010.88.2.234.

- Bakker, A. B. (2005). Flow among music teachers and their students: the crossover between peak experiences. Journal of Vocational Behavior. doi:10.1016/j.jvb.2003.11.001.

- Bakker, A. B., \& Demerouti, E. (2007). The job demands-resources model: state of the art. Journal of managerial psychology, 22(3), doi: 10.1108/02683940710733115.

- Bakker, A. B., \& Demerouti, E. (2008). Towards a model of work engagement. Career Development International. doi:10.1108/1362043081087047ㅁ․

- Bakker, A. B., Demerouti, E., de Boer, E., \& Schaufeli, W. B. (2003). Job demands and job resources as predictors of absence duration and frequency. Journal of Vocational Behavior. doi:10.1016/Sooo1-8791(02)00030-1.

- Bakker, A. B., Hakanen, J. J., Demerouti, E., \& Xanthopoulou, D. (2007). Job resources boost work engagement, particularly when job demands are high. Journal of Educational Psychology. doi:10.1037/0022-0663.99.2.274.

- Bakker, A. B., Schaufeli, W. B., Leiter, M. P., \& Taris, T. W. (2008). Work engagement: an emerging concept in occupational health psychology. Work and Stress.

doi:10.1080/02678370802393649.

- Balducci, C., Fraccaroli, F., \& Schaufeli, W. B. (2010). Psychometric properties of the Italian version of the Utrecht Work Engagement Scale (UWES-9). European Journal of Psychological Assessment. doi:10.1027/1015-5759/a000020.

- Beier, M. E., \& Ackerman, P. L. (2003). Determinants of health knowledge: an investigation of age, gender, abilities, personality, and interests. Journal of Personality and Social Psychology. doi:10.1037//0022-3514.84.2.439. 
- Borgogni, L., Galati, D., Petitta, L., \& Schweitzer, C. F. (2005). Il questionario checkup organizzativo. Manuale dell'adattamento italiano [The organizational checkup questionnaire. Manual of the Italian version]. Firenze: O.S. Organizzazioni Speciali.

- Borman, G. D., \& Dowling, N. M. (2008). Teacher attrition and retention: a meta- analytic and narrative review of the research. Review of Educational Research. doi:10.3102/0034654308321455.

- Canrinus, E. T., Helms-Lorenz, M., Beijaard, D., Buitink, J., \& Hofman, A. (2012). Selfefficacy, job satisfaction, motivation and commitment: exploring the relationships between indicators of teachers' professional identity. European Journal of Psychology of Education. doi:10.1007/s10212-011-0069-2.

- Cohen, J. (1969). Statistical power analysis for the behavioural sciences. New York: Academic Press.

- Cohen, J. (1998). Statistical power analysis for the behavioural sciences (2nd ed.). Hillsdale: Lawrence Erlbaum Associates.

- Day, C., Stobart, G., Sammons, P., Kington, A., Gu, Q., Smees, R., \& Mujtaba, T. (2006). Variations in teachers' work, lives and effectiveness. London: Department for Education and Skills. http://dera.ioe.ac.uk/6405/1/rr743.pdf.

- Demerouti, E., Bakker, A. B., Nachreiner, F., \& Schaufeli, W. B. (2001). The job demandsresources model of burnout. Journal of Applied Psychology, 86(3), 499.

- Depolo, M. (1998). L’ingresso nel mondo del lavoro: $i$ comportamenti di individui e organizzazioni. Roma: Carocci.

- Esteve, J. M. (2000). The transformation of the Teachers' role at the End of the twentieth century: new challenges for the future. Educational Review, 52(2), 197-207.

- Farrell, T. S. C. (2014). I feel like I’ve plateaud professionally...gone a little stale': midcareer reflections in a teacher discussion group. Reflective Practice. doi:10.1080/14623943.2014.900029.

- Fernet, C., Lavigne, G. L., Vallerand, R. J., \& Austin, S. (2014). Fired up with passion: investigating how job autonomy and passion predict burnout at career start in teachers. Work and Stress. doi:10.1080/02678373.2014.935524.

- Ghosh, P., Rai, A., \& Sinha, A. (2014). Organizational justice and employee engagement: exploring the linkage in public sector banks in India. Personnel Review. doi:10.1108/PR08-2013-0148.

- Guglielmi, D., \& Sarchielli, G. (2006). Psychologist profession: development of competences and professionalisation process. Psychologie du Travail et des Organisations. doi:10.1016/j.pto.2006.06.006.

- Guglielmi, D., Pamplomatas, A., Simbula, S., \& Depolo, M. (2011). Prevenzione dello stress lavoro correlato: validazione di uno strumento per la valutazione dei rischi psicosociali nella scuola. Psicologia della Salute. doi:10.3280/PDS2011-003003.

- Hackman, J. R., \& Oldham, G. R. (1980). Work redesign (Vol. 72). Reading: AddisonWesley. 
- Hakanen, J. J., Bakker, A. B., \& Schaufeli, W. B. (2006). Burnout and engagement among teachers. Journal of School Psychology. doi:10.1016/.j.jps.2005.11.001.

- Hildebrandt, S. A., \& Eom, M. (2011). Teacher. Professionalization: Motivational Factors and the Influence of Age. Teaching and Teacher Education. doi:10.1016/j.tate.2010.09.011.

- Hinkin, T. R., \& Schriesheim, C. A. (2008). An examination of "nonleadership": from laissez-faire leadership to leader reward omission and punishment omission. Journal of Applied Psychology. doi:10.1037/ao012875.

- Hinkle, D. E., Wiersma, W., \& Jurs, S. G. (2003). Applied statistics for the behavioral sciences (5th ed.). Boston: Houghton Mifflin.

- Høigaard, R., Giske, R., \& Sundsli, K. (2012). Newly qualified teachers' work engagement and teacher efficacy influences on job satisfaction, burnout, and the intention to quit. European Journal of Teacher Education. doi:10.1080/02619768.2011.633993.

- Hu, Q., Schaufeli, W. B., \& Taris, T. W. (2011). The job-demands-resources model: an analysis of additive and joint effects of demands and resources. Journal of Vocational Behavior. doi:10.1016/j.jvb.2010.12.009.

- James, J. B., McKechnie, S., \& Swanberg, J. (2011). Predicting employee engagement in an age-diverse retail workforce. Journal of Organizational Behavior. doi:10.1002/job.681.

- Kahn, W. A. (1990). Psychological conditions of personal engagement and disengagement at work. Academy of Management Journal, 33, 692-724.

- Kanfer, R., \& Ackerman, P. L. (2004). Aging, adult development, and work motivation. The Academy of Management Review. doi:10.2307/20159053.

- Lauermann, F. (2014). Teacher responsibility from the teacher's perspective. International Journal of Educational Research. doi:10.1016/j.ijer.2013.09.005.

- Lauermann, F., \& Karabenick, S. A. (2011). Taking teacher responsibility into account (ability): explicating its multiple components and theoretical status. Educational Psychologist. doi:10.1080/00461520.2011.558818.

- Lavigne, A. L. (2014). Beginning teachers who stay: beliefs about students. Teacher and Teaching Education. doi:10.1016/j.tate.2013.12.002.

- Le Cornu, R. (2013). Building early career teacher resilience: the role of relationships. Australian Journal of Teacher Education, 38(4), 1-16.

- Lee, J., \& Ok, C. (2015). Drivers of work engagement: an examination of core selfevaluations and psychological climate among hotel employees. International Journal of Hospitality Management. doi:10.1016/j.jjhm.2014.10.008.

- Lorente, L., Salanova, M., Martínez, I. M., \& María, V. (2014). How personal resources predict work engagement and self-rated performance among construction workers: a social cognitive perspective. International Journal of Psychology, 49(3), 200-207.

- Mansfield, C., Beltman, S., \& Price, A. (2014). I'm coming back again!' The resilience process of early career teachers. Teachers and Teaching: Theory and Practice. doi:10.1080/13540602.2014.937958.

- Maslach, C., \& Leiter, M. P. (2008). Early predictors of job burnout and engagement. Journal of Applied Psychology. doi:10.1037/0021-9010.93.3.49‥ 
- Matteucci, M.C., \& Guglielmi, D. (2014). Personal sense of responsibility and work engagement in a sample of Italian high school teachers. Proceedings of EDULEARN14 Conference 7th-9th July 2014, Barcelona, Spain, 5673-5677.

- Mauno, S., Kinnunen, U., Mäkikangas, A., \& Nätti, J. (2005). Psychological consequences of fixed-term employment and perceived job insecurity among health care staff. European Journal of Work and Organizational Psychology. doi:10.1080/13594320500146649.

- MOW - International Research Team. (1987). The meaning of working: an international perspective. London: Academic Press.

- Nunnally, J. C., \& Bernstein, I. H. (1994). Psychometric theory (3rd ed.). New York: McGraw-Hill.

- Panari, C., Guglielmi, D., Simbula, S., \& Depolo, M. (2010). Can an opportunity to learn at work reduce stress? A revisitation of the job demand-control model. Journal of Workplace Learning. doi:10.1108/13665621011028611.

- Pitt-Catsouphes, M., \& Matz-Costa, C. (2008). The multi-generational workforce: findings from the age \& generations study. Issue brief No. 2O. Chestnut Hill: Sloan Center on Aging \& Work at Boston College. https://www.bc.edu/content/dam/files /research sites/agingandwork/pdf/publications/IB20 Engagement.pdf.

- Richardson, J. T. E. (2011). Eta squared and partial eta squared as measures of effect size in educational research. Educational Research Review. doi:10.1016/j.edurev.2010.12.001.

- Rizzo, J. R., House, R. J., \& Lirtzman, S. I. (1970). Role conflict and ambiguity in complex organizations. Administrative Science Quarterly, 15, 150-163.

- Robinson, D., Perryman, S., \& Hayday, S. (2004). The drivers of employee engagement. Report No. 408. London: Institute Employment Studies. http://www.employmentstudies.co.uk/summary/summary.php?id=408.

- Rothbard, N. P. (2001). Enriching or depleting? The dynamics of engagement in work and family roles. Administrative Science Quarterly, 46(4), 655-684.

- Runhaar, P., Sanders, K., \& Konermann, J. (2013). Teachers' work engagement: considering interaction with pupils and human resources practices as job resources. Journal of Applied Social Psychology. doi:10.1111/jasp.12155.

- Ryan, R. M., \& Deci, E. L. (2000). Self-determination theory and the facilitation of intrinsic motivation, social development, and well-being. American Psychologist. doi:10.1037//o003-066X.55.1.68.

- Saks, A. M. (2006). Antecedentes and consequences of employee engagement. Journal of Managerial Psychology, 21(7), 600-619.

- Salanova, M., Agut, S., \& Peirò, J. M. (2005). Linking organizational resources and work engagement to employee performance and customer loyalty: the mediation of service climate. Journal of Applied Psychology. doi:10.1037/0021-9010.90.6.1217.

- Santavirta, N., Solovieva, S., \& Theorell, T. (2007). The association between job strain and emotional exhaustion in a cohort of 1,028 Finnish teachers. British Journal of Educational Psychology. doi:10.1348/00070990픔2045. 
- Schaufeli, W. B., \& Bakker, A. B. (2004). Job demands, job resources, and their relationship with burnout and engagement: a multi-sample study. Journal of Organizational Behavior. doi:10.1002/job.248.

- Schaufeli, W. B., Salanova, M., González-Romá, V., \& Bakker, A. B. (2002). The measurement of engagement and burnout: a two sample confirmatory factor analytic

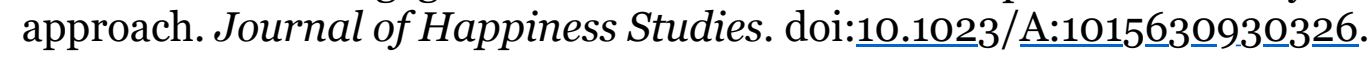

- Schaufeli, W. B., Bakker, A. B., \& Salanova, M. (2006). The measurement of work engagement with a short questionnaire: a cross-national study. Educational and Psychological Measurement. doi:10.1177/0013164405282471.

- Schwarzer, R., \& Knoll, N. (2007). Functional roles of social support within the stress and coping process: a theoretical and empirical overview. International Journal of Psychology. doi:10.1080/00207590701396641.

- Simbula, S., Guglielmi, D., \& Schaufeli, W. B. (2011). A three-wave study of job resources, self-efficacy, and work engagement among Italian schoolteachers. European Journal of Work and Organizational Psychology. doi:10.1080/13594320903513916.

- Somech, A., \& Drach-Zahavy, A. (2000). Understanding extra-role behavior in schools: the relationships between job satisfaction, sense of efficacy, and teachers' extra-role behaviour. Teaching and Teacher Education, 16(5), 649-659.

- Sortheix, F. M., Dietrich, J., Chow, A., \& Salmela-Aro, K. (2013). The role of career values for work engagement during the transition to working life. Journal of Vocational Behavior. doi:10.1016/j.jvb.2013.07.003.

- Struyven, K., Jacobs, K., \& Dochy, F. (2013). Why do they want to teach? The multiple reasons of different groups of students undertaking teacher education. European Journal of Psychology of Education, 28(3), 1007-1022.

- Super, D. E. (1957). The psychology of careers. New York: Harper \& Row.

- Timms, C., Graham, D., \& Cottrell, D. (2007). I just want to teach. Journal of Educational

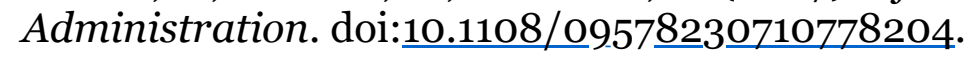

- Van der Heijden, B. I. J. M. (1998). The measurement and development of professional expertise throughout the career. Enschede: Partner Ipskamp

- Van der Heijden, B. I. J. M. (2006). Age differences in career activities among higher-level employees in the Netherlands: a comparison between profit sector and non-profit sector staff. International Journal of Training and Development, 1O(2), 98-120. 